\title{
Not Known if Lymph Node Dissection Was Performed
}

National Cancer Institute

\section{Source}

National Cancer Institute. Not Known if Lymph Node Dissection Was Performed. NCI

Thesaurus. Code C160458.

An indication that it is not known whether lymph node dissection was performed during the study. 